\title{
Collaboration for a curriculum of caring: the zeitgeist is right
}

\author{
Emily R. Smith \\ Fairfield University, esmith@fairfield.edu \\ Paula Gill Lopez \\ Fairfield University, pgilllopez@fairfield.edu
}

Follow this and additional works at: https://digitalcommons.fairfield.edu/education-facultypubs Copyright 2016 Wiley. A post print has been archived with permission from the copyright holder.

\section{Repository Citation}

Smith, Emily R. and Gill Lopez, Paula, "Collaboration for a curriculum of caring: the zeitgeist is right" (2016). GSEAP Faculty Publications. 120.

https://digitalcommons.fairfield.edu/education-facultypubs/120

\section{Published Citation}

Smith, Emily R., and Paula Gill Lopez. "Collaboration for a curriculum of caring: the zeitgeist is right." Psychology in the Schools 53, no. 3 (January 2016): 270-285. DOI: 10.1002/pits. 21898

This item has been accepted for inclusion in DigitalCommons@Fairfield by an authorized administrator of DigitalCommons@Fairfield. It is brought to you by DigitalCommons@Fairfield with permission from the rightsholder(s) and is protected by copyright and/or related rights. You are free to use this item in any way that is permitted by the copyright and related rights legislation that applies to your use. For other uses, you need to obtain permission from the rights-holder(s) directly, unless additional rights are indicated by a Creative Commons license in the record and/or on the work itself. For more information, please contact digitalcommons@fairfield.edu. 


\section{Collaboration for a Curriculum of Caring: The Zeitgeist is Right}

"We carry with us, as human beings, not just the capacity to be kind, but the very choice of kindness."

Wonder, R. J. Palacio

Conversations about care are on the minds of many in the wake of ongoing violence in schools and communities. Stories of violence are particularly disturbing when they occur in schools, where children are both victims and perpetrators. Too often, this violence is linked to bullying. While the number of homicides committed in schools has decreased since 1994, the percentage of students reportedly being bullied at least once a week has steadily increased since 1999 (Booth, Van Hasselt, \& Vecchi, 2011). Despite these realities, students still rank their high achievement and happiness as more important than care for others (Hough, 2014). American schools' overemphasis on academic achievement is taking its toll on our youth.

Recent catastrophic school shootings have drawn world-wide attention to issues of gun violence and control and have pushed issues of mental health to the forefront of national conversations. Though bullying, rejection and other mental health issues are often involved in school homicides and suicides (Leary, Kowalski, Smith \& Phillips, 2003; The Sandy Hook Advisory Committee, 2015), school violence-prevention efforts have tended to focus on the tools of violence, charging schools to create weapon-free environments and crisis management plans. These efforts, though well-intentioned, are both reactionary and isolated, and sidestep the need to support children whose mental health and well-being are in jeopardy.

Horrific school shootings have served as a wake-up call to the alarming rise in mental health illness and needs in this country (Koller \& Bertel, 2006; The Sandy Hook Advisory Committee, 2015). Nationally, about one in five youth experience a diagnosable, treatable socialemotional-behavioral problem; however, only about 20 percent of these youth receive the help 
they need (National Center for Mental Health Promotion and Youth Violence Prevention, 2011). In response, some schools are adopting social and emotional learning (SEL) programs or considering SEL standards (Jones \& Bouffard, 2012). However, research on how to teach SEL is relatively new. Here, we share our efforts to make care and SEL central components of curricula, rather than tangential strands woven in in the wake of tragedy (Lamm, 1999; vanWestervelt, 2002). We describe our collaboration as university faculty to prepare school psychology and English teacher students to collaboratively design a curriculum of care in English classrooms.

\section{Teaching Social and Emotional Learning}

\section{The Call to Care}

Calls to integrate care and SEL into the curriculum are not new. Over 20 years ago Noddings (1992) critiqued educational systems for prioritizing academic achievement and tests over education that values care for people and the world. Noddings (1995), among others (e.g., Charney, 2002; Kohn, 2000; O’Brien, Weissberg \& Shriver, 2003; Splitter, 2009; Watson, 2004), argues for a curriculum that puts understanding and caring for self and others at the center of the curriculum. In the midst of increasing school violence, schools are beginning to heed this call to help children develop the SEL skills needed to successfully navigate life.

Elias and colleagues (1997) define SEL as the process of developing skills to recognize and manage emotions, set and achieve goals, engage in perspective-taking, establish and manage interpersonal relationships and conflicts, and make responsible decisions. The Collaborative for Social-Emotional and Academic Learning (CASEL, 2012) identifies five core SEL competencies that should be taught in school: self-awareness, self-regulation, social awareness or perspectivetaking, relationship skills, and consequential decision making. With more and more educational 
researchers documenting the benefits of SEL instruction, the time is right for innovative approaches to integrating SEL into P-12 curricula.

\section{Benefits of Social Emotional Learning}

Though families and communities play a key role in preventing school violence, schools can play an important role in creating safe climates through SEL programming (CASEL, 2012; The Sandy Hook Advisory Committee, 2015). A growing evidence base supports the teaching of social-emotional content in schools to improve students' conduct, attitudes and academic performance, including two seminal meta-analyses. In 2008, Payton and colleagues analyzed three major reviews of research covering 317 studies exploring the effects of SEL interventions on a total of 324,303 K-8 youth (Payton, Weissberg, Durlak, Dymnicki, Taylor, Schellinger \& Pachan, 2008). Their analysis examined the outcomes of various during or after school SEL programs with participants who were identified as having signs of behavioral or emotional problems (indicated sample), as well as those who weren't identified (universal sample). The second meta-analysis (Durlak, Weissberg, Dymnicki, Taylor \& Schellinger, 2011) analyzed 217 studies that examined the effects of in-school SEL programming on $270,034 \mathrm{~K}-12^{\text {th }}$ graders, none of whom were identified as having signs of emotional problems (universal-only sample).

Both meta-analyses explored the same six dependent variables and found significantly more positive outcomes on all variables for children who had SEL programming, as compared to the control groups. The six variables, with corresponding effect sizes for the universal samples for the respective analyses ( $\mathrm{n}=180$ studies for Payton et al./n=213 studies for Durlak et al.), include: social and emotional skills $(.60 * / .57 *)$; attitudes toward self and others $(.23 * / 23 *)$; positive social behavior $(.24 * / .24 *)$; conduct problems $(.23 * .22 *)$; emotional distress $(.23 * / .24 *)$; and academic performance $(.28 * / .27 *)$. 
Payton et al. (2008) found the mean effect sizes for students in the indicated sample ( $\mathrm{n}=80$ studies) were larger than those in the universal condition ( $\mathrm{n}=180$ studies) respectively, as follows: social and emotional skills $(.77 * / .60 *)$; attitudes toward self and others $(.38 * / .23 *)$; positive social behavior $(.50 * / .24 *)$; conduct problems $(.47 * / .23 *)$; emotional distress $(.50 * / .23 *)$; and academic performance $(.43 * / .28 *)$ This suggests that SEL programming may have a more significant impact on students with higher risk for aggressive behavior, which others have also found (Lösel \& Beelmann, 2003; McGuire, 2008; Wilson \& Lipsey, 2007). Additionally, both meta-analyses found that interventions that adhered to evidence-based training practices had the largest effect sizes. In particular, interventions that are "SAFE" (sequenced, active, focused and explicit) positively influenced student outcomes (Payton et al., 2008; Durlak, Weissberg \& Pachan, 2010; Durlak et al., 2011).

Specific findings for children who have participated in SEL programs, as compared to those in control groups, include: performing better in school and having better attendance records; being less disruptive; being more connected to school; having fewer suspensions or other discipline issues; exhibiting better social relationships; being more motivated to learn; and showing fewer anti-social, violent, and drug-using behaviors (as cited in Durlak et al., 2011; Payton et al., 2008; Zins, Weissberg, Wang \& Walberg, 2004). Participants who experienced a school-based SEL program not only demonstrated improved social-emotional skills, but also showed an 11-17 percentile-point gain on standardized tests (Durlak et al., 2011). Additionally, SEL interventions were found to have positive effects for racially, ethnically, socioeconomically, and geographically diverse students (Durlak \& Weissberg, 2011; Payton et al., 2008). Finally, findings demonstrated positive outcomes for students in SEL programs that equaled or were greater than comparable outcomes for other prosocial prevention programs 
(Payton et.al, 2008). Our collaboration builds on the significance and strength of this research, working towards the healthy development of all children through SEL-infused curricula.

\section{National Initiatives}

Recent federal initiatives also call for SEL programming in schools. The U.S. Department of Education's Office of Civil Rights published guidance for schools to address harassment and bullying ("stopbullying," n.d.). The National School Climate Council (2010) developed the National School Climate Standards, which highlight the development of SEL skills as a means to prevent and address bullying. Most recently, three federal bills were introduced that specifically mandate SEL instruction in schools (http://www.casel.org/federalpolicy-and-legislation/). Taken together, H.R. 497 (January 2015), H.R. 850 (February 2015), and S. 897 (April 2015) highlight the importance of supporting research on the implementation of evidence-based SEL practices and programming; promote the positive research findings associated with SEL; and amend the Elementary and Secondary Education Act (ESEA) to allow SEL professional development funding for school personnel.

\section{Impediments to Teaching Social Emotional Learning}

Efforts to actualize SEL legislation must contend with current educational priorities that prioritize academic outcomes. SEL lessons are typically relegated to "push-in" or "pull-out" efforts, separate from the regular curriculum. Despite growing evidence supporting the positive impact of SEL, current accountability systems (e.g., standardized testing, teacher evaluation systems) do not encourage or support teachers to forefront SEL in the curriculum (Education Week Research Center, 2015; Nagel, Lockner, Hollis, \& Napper-Owen 2003). Initiatives such as No Child Left Behind and the CCSS reinforce academic outcomes and teacher training standards that are "ever more narrowly defined by subject matter pedagogical skills," thereby leaving "the 
development of positive social and emotional skills of youth...to chance" (Koller \& Bertel, 2006, p. 202). Instruction in SEL falls to support professionals, whose work resides largely outside the official curriculum, not evaluated by the measures that count in school. If we are serious about the need to prepare caring citizens, we must teach care in our standard curriculum. We must support educators to create safe classrooms, not only through whole-school prevention efforts or mini lessons squeezed into curricula (Jones, Brown, Hoglund, \& Aber, 2010), but also through deliberate and collaborative teaching in the required curriculum and classroom.

Recently, SEL research has begun to focus on efforts to integrate SEL into the curriculum. Some note the natural links between academic and SEL standards, and encourage educators to make deliberate curricular connections, while others promote the integration of SEL practices into the daily life of the school community (Civic Enterprises, Bridgeland, Bruce \& Hariharan, 2013; Horner, Sugai \& Anderson, 2010; Kress, Norris, Schoenholz, Elias \& Seigle, 2004; Ttofi \& Farrington, 2011; Yoder, 2014). However, because efforts to integrate SEL into the curricula are new, there is little documentation of integrated practices (Jones \& Bouffard, 2012). While the introduction of federal legislation mandating training in SEL programming may promote more research in this area, much needs to change to make integrated SEL possible. The effort described here is one way to implement the new federal initiatives.

SEL integration requires several paradigmatic and cultural shifts in education. First, it requires a movement away from reactive, one-on-one consultation and intervention models for at-risk students to primary prevention, where teachers play a key role in mental health education and prevention for all students (Berzin, O’Brien, Frey, Kelly, Alvarez, \& Shaffer, 2011; Koller \& Bertel, 2006). Second, P-12 teachers need preparation in mental health education. Most teachers receive little-to-no preparation in mental health education or intervention during teacher 
preparation and feel unprepared to address mental health issues in their classrooms (ASCD, 2000a; Koller, Osterlind, Paris \& Weston, 2004; Nagel, Lockner, Hollis, \& Napper-Owen, 2003; Schonert-Reichl \& Zakrzewski, 2014). Though there is strong agreement that SEL training and support is necessary for all educators (Civic Enterprises, Bridgeland, Bruce \& Hariharan, 2013; Domitrovich \& Greenberg, 2000; Yoder, 2014), “[t]raining in supporting SEL in ongoing ways is virtually unheard of' (Jones \& Bouffard, 2012, p. 13). Third, teachers and support staff must learn to collaborate in SEL delivery. Jones and Bouffard's (2012) review of SEL implementation studies found that "students were more likely to benefit when programs... reflected collaborative efforts among all staff and stakeholders" (p. 7), as effective school-based mental health programs incorporate a variety of personnel (Anderson-Butcher \& Ashton, 2004).

Examples of what such collaboration might look like, or how teachers and support professionals are prepared to engage in it, are relatively scarce. As Berzin et al. (2011) note, the literature "does little to promote our understanding of how school mental health personnel and teachers collaborate to serve students' emotional and behavioral health needs" (p. 494). Efforts to integrate SEL in the curriculum must begin in educator preparation, where classroom teachers and support professionals develop the knowledge, skills and dispositions needed to collaboratively prepare today's students with both the academic and SEL skills needed to be competent and caring citizens. Our work begins to address these gaps in the field and literature, sharing an inter-disciplinary collaboration among faculty and graduate students from School Psychology and English Education to co-design standards-based English curricula that foreground SEL skills. In what follows, we describe our collaborative planning and teaching, as well as the qualitative analysis of the outcomes of this collaboration.

\section{Description of Practice}




\section{Background \& Participants}

We_-Paula, a school psychologist, and Emily, an English educator — are colleagues in a graduate school of education at a private university in Northeastern United States. Immediately following the horrific events of December 14, 2012 in Newtown, we grappled with ways to support our preservice school psychology and English education students to make sense of this tragedy and prepare for their future work in schools. We facilitated a forum in January 2013 for university and community members to process the tragedy. At the state level, arrangements were made by university trainers to host PREPaRE workshops to help schools strengthen their safety and crisis management plans. Nationally, The National Council of Teachers of English encouraged English teachers to take up issues of care, empathy and understanding through the teaching of literature and writing. These responses to the tragedy were thoughtful, but they were also isolated and reactionary. We wanted to focus our energies on preventing school tragedies, rather than just responding to them. From here, a collaboration was born, focused on ways to create classrooms where all children learn to care for themselves and others.

Following the university forum, we brainstormed ways to combine our expertise in school psychology and English education to prepare our students to play a role in creating safe schools. We realized that the forum was the first time our respective students had ever formally interacted. Though our students will eventually work in the same school buildings, they do not interact during their preparation programs. Thus, we determined that our students needed to work together and learn how to collaborate. Secondly, we agreed that a key step in creating safe schools involves supporting students' socio-emotional well-being. Third, we agreed that SEL instruction should be integrated into the required curriculum and accountability system. To these ends, we committed to preparing our students to collaboratively design literacy lessons that teach 
SEL competencies. Though our collaboration focuses on English lessons, the SEL-integration described herein can happen in other content areas, too.

Our collaborative instruction occurred in our June 2013 summer courses. Emily was teaching a course in Young Adult Literature to her English education graduate students ( $\mathrm{n}=9 ; 7$ females; 2 males) and Paula was teaching Counseling \& Group Process to her school psychology students ( $\mathrm{n}=8 ; 6$ females; 2 males). We identified a common class session when our students would meet together, having all read one of three pre-selected young adult texts. We co-taught our combined classes of students for four hours on June 24, 2013. With the success of this first co-taught class, we co-taught a second cohort of combined students for two hours on December 1, 2014 during Emily's English Methods course (n= 15; 13 females; 2 males) with Paula's internship students ( $\mathrm{n}=10 ; 8$ females; 2 males). In what follows, we describe how we collaboratively co-planned and co-taught lessons on integrating SEL in the English classroom.

\section{Co-Planning}

In late Spring 2013 we met several times to design a lesson that would scaffold our students to co-plan English lessons that teach and assess both literacy and SEL outcomes. First, we identified three young adults texts from Emily's syllabus around which our students would plan lessons: Wonder, by Palacio (2012); Give a Boy a Gun, by Strasser (2002); and Mockingbird, by Erskine (2011). These texts were selected for their focus on themes of care, diversity, and perspective-taking. Second, we discussed typical ways that English teachers and school psychologists independently teach or address the themes presented in each text (e.g., bullying, disability, resilience, etc.) and then brainstormed how English teachers and school psychologists might collaboratively engage students with these texts. In the process, we examined both literacy (CCSS) and SEL standards to identify sample lesson outcomes. Unlike 
literacy standards, SEL standards are not mandated in all 50 states. Only a few states have comprehensive, free-standing K-12 SEL standards with developmental benchmarks (Dusenbury, Weissberg, Goren \& Domitrovich, 2014). We were intent on having students create standardsbased lessons to help students align and evaluate both academic and SEL outcomes. Third, we scanned web resources for sample lessons plans that integrated ELA and SEL outcomes. As expected, very few lessons made the SEL outcomes explicit or evaluated them. Fourth, we created an integrated lesson plan template that targeted literacy and SEL outcomes. Finally, we identified our respective roles during the co-taught lesson. Given the success of the first lesson, we did not make many changes to the plans during our second co-planning in the Fall 2014, except for condensing each part of the lesson to fit the two-hour class period.

\section{Co-Teaching}

We began each class by sharing the origin and rationale for this collaboration, and the plan for the day. During introductions, students shared personal responses to the text they read. Students were then divided into groups of four or five according to the book they read; each group included students from English education and school psychology. Groups brainstormed themes in their text to generate potential foci for their lesson plan. We then distributed and explained the CCSS and SEL standards as a framework for their lessons. Their charge, we explained, was to collaboratively plan a lesson that targeted both SEL and literacy standards, drawing on their peers' respective knowledge of lesson planning and SEL. We provided several resources, including a sample integrated lesson plan and the lesson plan template we created, and we were available to answer questions and provide suggestions as they worked.

Student groups worked on their plans for an hour. They chose a theme/issue; identified relevant SEL and literacy standards; and brainstormed activities, discussion questions, writing 
prompts, scenarios, role-plays, and evaluation strategies. Each group presented a "walkthrough" of their lesson to the entire class. The lesson plans were thoughtful and creative, greatly exceeding our modest expectations for their first attempt at this type of collaboration.

This collaborative SEL intervention exemplifies two important features of best practices recommended in the literature. First, our approach reflects the SAFE framework for SEL skill development (Gresham, 1995; Payton et al., 2008; Durlak et al., 2011), including a sequenced, step-by-step plan for teaching SEL skills to students; active methods for learning (role-playing, writing, discussion); a consistent and enduring focus on the SEL skills; and explicit targeting of SEL standards. Second, research maintains that SEL programming is most effective when implemented by school personnel rather than university researchers or external consultants (Payton et al., 2008; Durlak et al., 2011). The SEL intervention described here is co-developed and co-taught by P-12 teachers and school psychologists, staff members of all public schools.

\section{Outcomes}

Data sources for the analysis of our outcomes include detailed notes from our coplanning and co-teaching sessions; written reflections on our co-teaching; and students' lesson plans and written reflections. Our qualitative, interpretive analysis (Erickson, 1986) focuses on whether our co-teaching successfully supported our students to collaboratively develop SELinfused lessons. We collected and analyzed data as participant observers. Our sustained contact during and after our co-teaching provided insider access to our and our students' experiences and the artifacts produced (Bogdan \& Biklen, 1992). Following the conclusion of our first co-taught class, we began a structured process of analyzing the data. We began with individual readthroughs to identify themes and patterns in the various sources of data. We then jointly coded students' reflections and lessons plans, as well as our field notes. We identified patterns related 
to students' experience in the lesson, and evaluated the coherence and structure of their lesson plans. We repeated this process after the second lesson, adding to and revising patterns as needed. From these analyses, we were able to identify several key outcomes from the collaborative experience and evaluate the quality of the SEL-infused lesson plans.

There are several positive outcomes from our joint classes, all of which underscore the value and possibility of this type of collaboration for integrating SEL in content classrooms. What's more, there were outcomes we did not anticipate, including students who subsequently tried this collaborative work on their own. Additional outcomes include: the integrated lesson plans; students' reflections on the experience; and revisions to our graduate coursework.

\section{Lesson Plans}

As we listened to the students present their completed lesson plans, we were amazed by their creativity and cohesiveness. Together, the students designed lessons that engaged secondary students in meaningful activities that tapped both literacy and SEL outcomes in authentic ways. For example, one group planned a sixth grade lesson on perspective-taking in Mockingbird around the following SEL and literacy standards:

SEL: Predict others' feelings and perspectives in a variety of situations (2A.3a); Analyze how one's behavior may affect others (2A.3b). (Illinois Board of Education) Reading: Cite textual evidence to support analysis of what the text says explicitly as well as inferences from the text; Writing: Write narratives to develop real or imagined experiences. (CCSS ELA)

The lesson involved discussing, reading and writing about perspective-taking in both the text and students' lives. After discussing what perspective means, students analyzed select passages from the perspective of various characters, inferring from the character's actions and words what s/he 
might be thinking or feeling. Students then rewrote a passage from the perspective of a character not in that scene. Finally, students were evaluated on a piece of writing that compared their own experience using perspective-taking to resolve a conflict with a like example from Mockingbird. A second group designed an eighth grade lesson on resiliency for Wonder that focused on the following standards (see Appendix):

SEL: Analyze how personal qualities influence choices and successes (1B.3a); Analyze how making use of school and community supports and opportunities can contribute to school and life success (1B.3b) (Illinois Board of Education) Reading: Determine a theme or central idea of a text and analyze its development over the course of the text; Analyze how an author develops and contrasts the points of view of different character or narratives in a text. (CCSS ELA)

Students are introduced to the concept of resiliency by analyzing the qualities and resources that enabled Lady Gaga's resilience. They then analyze the resiliency of characters from the text. Next, students analyze real-world scenarios to discuss how they would respond and act in familiar situations. For their assessment, students write personal narratives about times when they did not demonstrate resiliency.

The lessons were particularly impressive given some of the struggles the students experienced during their co-planning. As we circulated the classroom, we saw some groups struggling to coalesce, while others debated for lengthy times about which standards to address or which direction to take the lesson. We expected some struggle, as we were asking students who did not know each other to collaborate. What's more, they entered this task as novice planners and collaborators. However, students' reflections on the experience-across both classes - affirm that the experience, though challenging at times, was worthwhile and needed. 


\section{Student Reflections \& Insights}

At the end of each joint class, we asked students to reflect in writing on the collaboration, noting the benefits, challenges and take-aways from the experience. Reflections were obtained from 31 students. Several themes emerged across students' reflections on the benefits of the experience. Above all else, students noted the value-added of having the knowledge and perspectives from both English and school psychology to design the lessons ( $n=26)$. Having both professionals, the students felt, made the lessons richer, multidimensional, and more applicable to real life. They also gained new ideas and strategies for teaching $(n=18)$. As one English teacher wrote, "I liked listening to the other approaches [and] ways...[of] thinking about the lesson [and] planning from an SEL point of view." Students noted value for the secondary students, too, whom they felt would benefit from the combined resources of two professionals $(n=17)$. Some felt the integrated lessons would lead to deeper, more meaningful engagement with their reading as well as real-world strategies for navigating their social worlds $(n=16)$. Some of the school psychology students noted that the collaboration provides secondary students with more exposure to school psychologists, helping them to see them as "approachable" and not just for students who "have problems" $(n=5)$. Students noted that the co-teaching approach is proactive and reaches all students, not just those who are "identified," without losing class time to pull-out sessions $(n=12)$. Finally, many students were grateful for the increased understanding of their colleagues' work $(n=8)$. Some English teachers weren't aware of what school psychologists do, and appreciated learning about social-emotional content. Similarly, the school psychology students welcomed learning about lesson planning and the literacy standards, and where content teachers are "coming from" in their teaching and curricula. 
The most commonly noted challenge was merging multiple people's planning ideas into one lesson $(n=9)$. Less frequently cited challenges include: identifying complementary literacy and SEL standards and activities $(n=3)$; having enough time to complete the task $(n=3)$; making sure each discipline was respected $(n=2)$; creating a lesson without lesson-planning experience $(n=2)$; and creating flow in the lesson $(n=1)$. One student wrote, "It was challenging trying to get all 4 of our ideas into one lesson, but once we did...our lesson was great!" Students were initially self-conscious about their inexperience in their peers' field, in SEL instruction or lesson planning. Though uncomfortable at first, students' varied expertise nurtured a healthy interdependence in the groups, with different students taking the lead on particular parts of the planning. Reflecting on the two classes ourselves, we also felt the time pressure and the need for students to quickly develop working relationships. Additionally, we note the need to model how to facilitate the type of difficult classroom conversations that can emerge from these integrated lessons. While English teachers regularly facilitate literary discussions around sensitive topics (e.g., race, class, sexual identity), the integrated lessons encourage students to engage with these topics with respect to their own lives; the P-12 students become the "characters" whose interpersonal skills we analyze, and these conversations can be more difficult to navigate. In the future, we need to be more explicit about the role school psychologists, who are trained to facilitate conversations about students' personal decisions and behaviors, should play in this collaborative class to facilitate difficult conversations and navigate these emotional landmines.

Topping the list of students' take-aways was the feeling that this type of collaboration is both necessary and doable $(n=17)$. One student noted "how crucial and doable it is to incorporate SEL components in English classes and how it simultaneously helps [students] to engage with and understand literature and ourselves." Both English education and school psychology students 
envisioned themselves seeking out this type of collaborative planning and teaching in their future school settings, understanding the importance of infusing social-emotional skills into academic lessons $(n=18)$. For some, this collaborative class filled a gap in their professional preparation:

As a future English teacher, this is what I hope to do every day: facilitating discussions and experiences that not only make students better readers and writers, but [also] better friends, teammates, sons and daughters, and future "big people." This was the missing link for me.

Finally, the co-planning experience highlighted the importance of developing relationships with their colleagues to support collaboration $(n=21)$. Collectively, students' reflections underscore the value of this collaboration for secondary students, English teachers and school psychologists.

\section{Follow-Up Work in the Schools}

Several of the students from the joint summer class chose to engage in collaborative, integrative SEL work outside of their required Fall 2003 field and course work. For example, Heather planned a conceptual unit focused on in-crowds and outcasts for her English methods course. In describing the unit goals, Heather reflects her newly developed commitment to integrating SEL competencies into her literacy unit:

I hope to engage students in reflecting on the concepts [of in-crowds and outcasts] and the impact such social hierarchies have on them and others. At the same time, I hope to guide them as they develop perspective-taking skills, not only through the characters in their reading, but through their own experiences, with the aim of helping them become thoughtful, kind, and open members of their communities. As emphasized in the collaborative class, Heather's unit evaluates both literacy and SEL skills: 
Unit Assessment: Taking the perspectives of characters in their literature circle books, students will create either a letter or a dialogue that demonstrates mastery of the unit's language and writing skills, shows proficiency in perspective-taking, and reflects the student's own social-emotional growth in relation to the unit's themes. Heather's unit seamlessly integrates literacy and SEL outcomes, demonstrating the ease with which such integration can occur in content classrooms.

Stacie, a school psychology student, pursued a collaboration with an English teacher in her internship placement. Describing her decision, she writes:

Before our collaborative class, I knew the more traditional way to teach SEL lessons was for support staff to push into classrooms, but that takes time away from classroom instruction and isn't consistent or nearly enough SEL for students. Collaborative lessons are a no-brainer, getting twice the information in the amount of time it takes for one lesson. It just made perfect sense to share this idea with educators in the school where I was interning. I hoped to empower the teacher I was working with to continue creating lesson plans using both standards and maybe to share what we did with others.

In the spring 2014, Stacie approached Hank, an English teacher at the high school where she was an intern, and he agreed to collaborate on an SEL-infused lesson. In the co-planning stage, Stacie shared with Hank some information about SEL standards, goals, competencies, and statistics, as well as the integrated lesson she created in the summer class. In their second co-planning session, they designed a lesson for Hank's ninth grade English class on Romeo and Juliet. The lesson focused on analyzing characters and using perspective-taking to better understand character actions. Students practiced analyzing scenes from the play and determining what a 
character might be thinking and feeling. They then used this perspective-taking skill to analyze what particular characters might have done differently had they known more about the other character in the episode. Finally, they discussed what is gained by understanding character conflicts from various perspectives and how this relates to their own lives. Reflecting on the lesson, Stacie notes that the students were very involved in the lesson and crafted well-thought narratives that assumed the perspective of another character. The lesson had an impact on Hank, too, who subsequently implemented SEL skills and standards in his four other classes.

\section{Graduate Program Revisions}

The success of the collaboration also prompted us to make changes to our graduate programs to include this work. For example, we've made the collaborative class a permanent feature in both of our programs. The English Methods course, structured around six pedagogical strategies, now has a seventh pedagogical strategy: integrating social-emotional learning: collaborating with school psychologists. In the School Psychology Program, Paula has added a new assignment to the School Psychology Internship course that requires students to collaborate with a content area teacher to co-plan and co-teach an SEL-infused lesson.

\section{Discussion \& Implications}

The qualitative outcomes of our collaborative work were largely positive. We expected some resistance to this work; however, both sets of students dived into the collaborative planning with minimal hesitation. Overall, they were extremely positive about the experience and its benefits for themselves and their future students. Their lesson plans were creative and powerful, and the students left the collaborative classes empowered to engage in this collaborative work. And finally, as mentioned, we have made this collaborative class a permanent component of the curricula in both the English Education and School Psychology programs. 
Taken together, our outcomes leave us hopeful about the possibility and possibilities of collaboratively integrating SEL into content classrooms. At the same time, they entreat us to consider what made this type of collaboration possible, and what needs to happen in educator preparation and P-12 schools to make collaborative, integrated planning and teaching a doable reality. Though our outcomes stem from the work of two faculty at one university, they provide important insights about the variables needed to make this collaboration possible.

\section{Collaboration}

Perhaps the most important ingredient in this work is professional collaboration. Collaboration is essential on many levels - among faculty members in institutions of higher education (IHE); among students across professional preparation programs; and among colleagues in P-12 schools. Unfortunately, collaboration is largely countercultural in education. P-12 schools and IHE are structured around norms of individualism, with single-teacher models and private, "egg carton" classrooms. Collaboration is at odds with teaching's "organizational and occupational traditions" in which teachers "rarely have occasion to talk to fellow teachers in detail about their work" (Little, 1990, pp. 314, 318). What's more, educators at all levels are evaluated and rewarded on their solo teaching efforts. Efforts to collaborate, thus, require educators to give time beyond their contractual responsibilities, which can exhaust even the most enthusiastic and generous collaborator. To complicate matters, graduate programs provide little room for students to interact, let alone work, with pre-professionals in other programs. Graduate curriculums are typically constrained by professional standards and licensing/certification requirements, allowing little room for cross-program work. In the context of these constraints, our collaborative work was supported by the very ingredients we promoted for our students' collaboration: relationship and interdependence, integration, and accountability. 


\section{Relationships}

Relationships were essential to making the collaboration work. Emily and Paula shared a trusting relationship as colleagues, which was essential when opening their pedagogy and classrooms to each other. This relationship was also important for managing the anxiety in working outside one's expertise. Like our students, we brought varying levels of expertise to the table-Paula in SEL standards and skills, and Emily in literacy and lesson planning. However, our secure relationship alleviated any worry about appearing ignorant or unskilled and instead helped us to take advantage of this interdependence. Our students did not have the benefit of this relationship coming into their co-planning, though they were quickly able to see the benefits of our and their complementary expertise. Successful collaboration in IHE and P-12 schools, thus, requires a commitment to relationship-building to ease concerns about autonomy and expertise.

\section{Integration}

Integration was a second essential feature of our work. Given the demands of being a faculty member and department chair, it was important that our collaboration not add a burdensome amount of work. Integrating the collaborative class into our existing courses-just as our students did—reduced this potential burden. Though it did take longer to plan together than individually, the benefits made up for the added time. It was certainly more enjoyable to plan together: to have someone with whom to discuss dilemmas and bounce ideas off of, and to supplement our respective strengths and weaknesses as planners and teachers. What's more, the co-teaching provided an opportunity to engage in joint reflection on our teaching practices.

\section{Accountability}

We entered our collaboration committed to modeling the value of this integrative, collaborative work for our students. We knew from experience and practice that the things that 
"count" in schools are those that are evaluated in the classroom. Thus, building our co-taught class into the syllabi and assignments of students' required courses gave value to the work and held students accountable for it. It sent a message that their ability to collaborate and integrate SEL skills into content lessons was as important as their ability to plan a writing lesson or craft an Individualized Education Plan. As educators, we know that we must model in training the practices we want our graduates to learn and enact. Thus, collaborative planning and teaching, as well as strategies for integrating SEL into content lessons, must be modeled, practiced and valued during preparation coursework.

\section{Making Collaboration a Reality}

The variables that supported our collaboration suggest several key changes for educator preparation and P-12 schools that are necessary to support this collaborative work.

Paradigm shift. First, there needs to be a conceptual shift in how we think about the roles of teachers and support professionals. Typically, teachers are tasked with students' academic preparation and school psychologists with their psychological and social-emotional well-being. This division impacts the way SEL support is delivered: it is separate from-and takes time away from — the required curriculum. The roles are also physically separated: a teacher can go weeks or even months without even seeing their building's school psychologist. However, we know that students are not neatly compartmentalized along professional lines and bring their integrated selves into our classrooms and offices. Students would be better served if professional roles were redefined to be more inclusive and holistic rather than siloed, so that everyone in a building is working towards preparing the whole student. Though we cannot expect teachers to know all that school psychologists know (and vice versa), it makes sense to collaborate given that school psychologists are already trained in SEL. Together, they can 
develop more cohesive ways of thinking about shared outcomes for students that integrate academic and social-emotional goals.

Structuring for collaboration. For this shift to occur, both P-12 schools and IHE must erode individualistic models of teaching and structurally support collaboration. Faculty in IHE must be supported to co-teach so that students experience both the value and practice of collaborative teaching. Such support might include rethinking how faculty teaching loads are calculated; revising rank and tenure guidelines to reward innovative co-teaching; and promoting the outcomes of collaborative teaching. Similarly, in P-12 settings, teachers and support professionals must have dedicated time in their schedules to plan and teach together. One collaborative structure might be to form SEL teams, similar to student assistance teams. With one school psychologist per building (typically), her/his expertise in SEL could be spread further if s/he worked with a team of teachers committed to SEL infusion. The team would be a resource for others in the school building to gain an understanding of SEL and how to integrate it.

Additionally, teachers and school psychologists need to learn how to collaborate, including both the skills of co-planning and co-teaching as well as strategies for building relationships and trust. These skills can be modeled and practiced during preservice preparation, and through whole-school professional development initiatives. P-12 schools and IHE will likely find that the increased collaboration and relationship-building will lead to more supportive and positive school climates as well as a reduction in educator burnout and stress.

Redefining priorities. Finally, and perhaps most significantly, there must be a cultural change about the purpose of schooling and its outcomes. In our current age of high-stakes testing and accountability, schools have been forced to prioritize academic outcomes at the cost of other goals. Integrating SEL outcomes into school curricula is a practical way to both value the 
importance of SEL and make its integration a reality. The emergence of SEL standards in a few states provides resources for schools to embrace SEL outcomes.

With the current movement for mental health education on our side, the zeitgeist is right for this type of collaborative, integrative work. The recommendations of the Final Report of the Sandy Hook Advisory Commission (2015) identify mental health as one of three areas requiring national attention. Specifically, the report indicates that "schools must play a critical role in fostering healthy child development...[and that h]ealthy social development...should be actively taught in schools." Additionally, "social-emotional learning must form an integral part of the curriculum from preschool through high school” (pp. 110-111). The collaborative efforts described herein take a proactive approach to addressing these recommendations in ways that are both doable and rewarding. We hope that efforts such as ours will continue to grow so that schools become places where all children feel loved, safe and able to focus on reaching their fullest potential. 


\section{References}

Anderson-Butcher D, Ashton D. (2004). Innovative models of collaboration to serve children, youths, families, and communities. Children \& Schools, 26(1), 39-53.

Association for Supervision and Curriculum Development (Spring, 2000a). Preparing teachers to teach health. Curriculum Update, 6.

Berzin, S. C., O’Brien, K. H. M., Frey, A., Kelly, M. S., Alvarez, M. E., Shaffer, G. L. (2011). Meeting the social and behavioral health needs of students: Rethinking the relationship between teachers and school social workers. Journal of School Health, 81, 493-501.

Bogdan, R. B., \& Biklen, S. K. (1992). Qualitative research for education: An introduction to theory and methods. Boston: Allyn \& Bacon.

Booth, B., Van Hasselt, V. B., \& Vecchi, G. M. (2011). Addressing school violence. FBI Law Enforcement Bulletin, 80(5), 1-9.

Collaborative for Social, Emotional, and Academic Learning. (2012). CASEL guide: Effective social and emotional learning programs. Retrieved from: http://www.casel.org/guide

Charney, R. (2002). Teaching children to care: Classroom management for ethical and academic growth, K-8 rev ed. United States of America: Northeast Foundation for Children.

Civic Enterprises., Bridgeland, J., Bruce, M., \& Hariharan, (2013). The Missing Piece: A National Teacher Survey on How Social and Emotional Learning Can Empower Children and Transform Schools. Collaborative for Academic, Social, and Emotional Learning. Chicago, IL: Author.

Council of Chief State School Officers \& The National Governors Association (2010). Common Core State Standards for English Language Arts \& Literacy in History/Social Studies, 
Science, and Technical Subjects. Retrieved from:

http://www.corestandards.org/assets/CCSSI_ELA\%20Standards.pdf

Dary, T., \& Pickeral, T. (Eds.) (2013). School Climate: Practices for Implementation and Sustainability (School Climate Practice Brief No. 1). New York, NY: National School Climate Center.

Domitrovich, C. E., \& Greenberg, M. T. (2000). The study of implementation: current findings from effective programs that prevent mental disorders in school-age children. Journal of Educational and Psychological Consultation, 11, 193-221.

Durlak, J.A., \& Weissberg, R.P. (2011). Promoting social and emotional development is an essential part of students' education. Human Development, 54, 1-3.

Durlak, J. A., Weissberg, R. P., Dymnicki, A. B., Taylor, R. D., \& Schellinger, K. B. (2011). The impact of enhancing students' social and emotional learning: A meta-analysis of schoolbased universal interventions. Child Development, 82, 405-432.

Durlak, J. A., Weissberg, R. P. \& Pachan, M. (2010). A meta-analysis of after-school programs that seek to promote personal and social skill in children and adolescents. American Journal of Community Psychology, 25, 115-152.

Dusenbury, L., Weissberg, R.P., Goren, P. \& Domitrovich, C. (2014). Standards to advance social and emotional learning: Findings from CASEL's state scan of social and emotional learning standards, preschool through high school. Retrieved from: http://static1.squarespace.com/static/513f79f9e4b05ce7b70e9673/t/52f95691e4b0a41cab a778b8/1392072337661/casel-brief-on-state-standards-january-2014.pdf 
Education Week Research Center. (2015). Social and emotional learning: Perspectives from America's schools. Retrieved from: http://www.edweek.org/media/ewrc_selreport_june2015.pdf.

Elias, M.J., Defini, J., \& Bergmann, J. (2010). Coordinating social-emotional and character development (SECD) initiatives improves school climate and student learning. Middle School Journal, 41, 30-37.

Elias, M. J., Zins, J. E., Weissberg, R. P., Frey, K. S., Greenberg, M. T., Haynes, N. M.,...Shriver, T. P. (1997). Promoting social and emotional learning: Guidelines for educators. Alexandria, VA: Association for Supervision and Curriculum Development.

Erickson, F. (1986). Qualitative methods in research on teaching. In M. C. Wittrock (Ed.), Handbook of research on teaching ( $3^{\text {rd }}$ ed.). New York: McMillan.

Erksine, K. (2010). Mockingbird. New York, NY: Philomel Books.

Federal Legislation to Promote Social and Emotional Learning. (n.d.). Retrieved from: http://www.casel.org/federal-policy-and-legislation/

Frey, K.S., Hirschstein, M.K, \& Guzzo, B.A. (2000). Second step: Preventing aggression by promoting social competence. Journal of Emotional and Behavioral Disorders, 8, 102112. doi: $10.1177 / 106342660000800206$

Gresham, F. M. (1995). Best practices in social skills training. In A. Thomas \& J. Grimes (Eds.), Best practices in school psychology-III (pp. 1021-1030). Washington, DC: National Association of School Psychologists.

Hayes, S. (2012). Responding to Tragedy in Schools: Supporting Teachers and Students. Retrieved from http://www.ncte.org/responding

Horner, R. H., Sugai, G., \& Anderson, C. M. (2010). Examining the evidence base for school- 
wide positive behavior support. Focus on Exceptionality, 42(8), 1-14.

Hough, L. (2014, September). How Teachers can make caring more common: Five tangible steps to foster a climate of mutual respect and caring in the classroom. Usable Knowledge: Connecting Research to Practice. Retrieved from: http://www.gse.harvard.edu/news/uk/14/09/how-teachers-can-make-caring-morecommon

Illinois State Department of Education. (n.d.). Illinois learning standards: Social emotional learning. Retrieved from: http://www.isbe.net/ils/social_emotional/standards.htm

Jones, S. M., \& Bouffard, S. M. (2012). Social and emotional learning in schools: From programs to strategies. Social Policy Report, 26(4), 1-32.

Jones, S. M., Brown, J. L., Hoglund, W., \& Aber, J.L. (2010). A school-randomized clinical trial of an integrated social-emotional learning and literacy intervention: Impacts after 1 school year. Journal of Consulting and Clinical Psychology, 78, 829-842. doi: $10.1037 / \mathrm{a} 0021383$

Kohn, A. (2000). The case against standardized testing. Portsmouth, NH: Heinemann.

Koller, J. R., \& Bertel, J. M. (2006). Responding to today's mental health needs of children, families and schools: Revisiting the preservice training and preparation of school-based personnel. Education \& Treatment of Children, 29, 197-217.

Koller J. R., Osterlind, S. J., Paris, K., Weston, K. J. (2004). Differences between novice and expert teachers' undergraduate preparation and ratings of importance in the area of children's mental health. International Journal of Mental Health Promotion, 6(2):40-46. doi: 10.1080/14623730.2004.9721930

Kress, J. S.; Norris, J. A.; Schoenholz, D. A.; Elias, M. J. \& Seigle, P. (2004). Bringing together 
educational standards and social and emotional learning: Making the case for educators. American Journal of Education, 111, 68-89.

Lamm, R. (1999). From grief, poetry: Expressive writings from the Westside tragedy. The Quarterly, 21, 2-7.

Leary, M.R., Kowalski, R. M., Smith, L., \& Phillips, S. (2003). Teasing, rejection, and violence: Case studies of the school shootings. Aggressive Behavior, 29, 202-214.

Little, J.W. (1990). The mentor phenomenon and the social organization of teaching. In C. Cazden (Ed), Review of Research in Education, 16 (pp. 297-351). Washington, DC: American Educational Research Association.

Lösel, F., \& Beelmann, A. (2003). Effects of child skills training preventing antisocial behavior: A systematic review of randomize evaluations. Annals of the American Academy of Political and Social Science, 587, 84-109.

McCallion, G. \& Feder, J. (2013). Student bullying: Overview of research, federal initiatives, and legal issues (CRS Report No. 7-5700-R43254). Retrieved from http://fas.org/sgp/crs/misc/R43254.pdf

McGuire, J. (2008). A review of effective interventions for reducing aggression and violence. Philosophical Transactions of the Royal Society, 363, 2577-2597, doi: $10.1098 /$ rstb.2008.0035.

Nagel, L., Lockner, D., Hollis, C., \& Napper-Owen, G. (2003). Integrating health education into teacher preparation programs: A case study. Action in Teacher Education, 25(2), 35-43.

National Center for Mental Health Promotion and Youth Violence Prevention, Education Development Center, Inc. (2011). Realizing the promise of the whole-school approach to children's mental health: A practical guide for schools. Retrieved from 
http://sshs.promoteprevent.org/webfm_send/2102

National School Climate Council. (2010). National school climate standards: Benchmarks to promote effective teaching, learning, and comprehensive school improvement. New York: Center for Social and Emotional Education.

Noddings, N. (1992). The challenge to care in schools: An alternative approach to education. New York, NY: Teachers College Press.

Noddings, N. (1995). Teaching themes of care. Phi Delta Kappan, 76, 675-679.

O’Brien, M., Weissberg, R. P., \& Shriver, T. P. (2003). Educational leadership for academic, social, and emotional learning. In M. J. Elias, H. Arnold, \& C. Steiger (Eds.), EQ + IQ = Best leadership practices for caring and successful schools (pp. 23-35). Thousand Oaks, CA: Corwin Press.

Palacio, R. J. (2012). Wonder. New York, NY: Knopf Books.

Payton, J., Weissberg, R.P., Durlak, J.A., Dymnicki, A.B., Taylor, R.D., Schellinger, K.B., \& Pachan, M. (2008). The positive impact of social and emotional learning for kindergarten to eighth-grade students: Findings from three scientific reviews. Chicago, IL: Collaborative for Academic, Social, and Emotional Learning.

Individuals with Disabilities Education Improvement Act of 2004, Pub. L. 108-446, 108th Congress.

Sandy Hook Advisory Committee. (2015). Final Report of The Sandy Hook Advisory Commission. Retrieved from http://www.shac.ct.gov/SHAC_Final_Report_3-6-2015.pdf Schonert-Reichl, K. \& Zakrzewski, V. (2014). How to Close the Social-Emotional Gap in 
Teacher Training. Retrieved from http://greatergood.berkeley.edu/article/item/how to_close the_social_emotional_gap_in $\underline{\text { teacher training\# }}$

Splitter, L. (2009). Caring for the "Self as One Among Others." Thinking: The Journal of Philosophy for Children, 19(4), 33-39.

Strasser, T. (2000). Give a Boy a Gun. New York, NY: Simon \& Schuster.

Ttofi, M. M., \& Farrington, D. P. (2011). Effectiveness of school-based programs to reduce bullying: A systematic and meta-analytic review. Journal of Experimental Criminology, 7, 27-56. doi: 10.1080/1754730X.2008.9715730

U.S. Department of Health \& Human Services. (2014). Stopbullying.gov. Retrieved from http://www.stopbullying.gov/laws/federal/index.html

VanWestervelt, R. (2002). Giving children a voice and venue after 9/11. The Voice, 7(4), 8-9.

Watson, M. (2004). A curriculum of care. Greater Good: The Science of a Meaningful Life, 1. Retrieved from http://greatergood.berkeley.edu/article/item/curriculum_of_care\#

Wilson, S. J., \& Lipsey, M. W. (2007). School-based interventions for aggressive and disruptive behavior: Update of a meta-analysis. American Journal of Preventive Medicine, 33 (Suppl. 2S), 130-143.

Yoder, N. (2014) Teaching the whole child: Instructional practices that support social and emotional learning in three teacher evaluation frameworks. Washington, DC: American Institutes for Research Center on Great Teachers and Leaders.

Zins, J. E., Weissberg, R. P., Wang, M. C., \& Walberg, H. J. (Eds.) (2004). Building academic success on social and emotional learning: What does the research say? NY: Teachers College Press. 
Appendix

\section{Sample Student-Produced Integrated Literacy \& Social Emotional Learning Lesson Plan}

Text: Wonder, Palacio (2012)

Grade Level: $8^{\text {th }}$

Lesson Focus: Resiliency

\section{Lesson Objective}

- Students will be able to identify qualities of resilience (or lack thereof) in both literary characters and themselves.

SEL Standards (Illinois State Board of Education)

- Analyze how personal qualities influence choices and successes (1B.3a);

- Analyze how making use of school and community supports and opportunities can contribute to school and life success (1B.3b)

Literacy Standards (CCSS, English Language Arts)

- Determine a theme or central idea of a text and analyze its development over the course of the text;

- Cite several pieces of textual evidence to support analysis of what the text says explicitly as well as inferences drawn from the text.

\section{Lesson Development}

\section{Initiation}

- School psychologist leads students in the completion and discussion of a 5-question Likert scale questionnaire focused on examples of resiliency (or lack thereof) and use it to develop a class definition of resiliency.

- Class listens to and reads lyrics of Lady Gaga's song, "Born This Way." Pointing students to the lyrics, English teacher facilitates discussion of the following questions:

1. What does Lady Gaga think of herself?

2. What qualities make Lady Gaga resilient or not? (cite specific lines to support your response)

3. What types of support did she draw on (family, school, friends, religion)?

Modeling 
- Using a pre-selected scene from Wonder, English teacher models analysis of how the character in the scene does or does not show resilience, using the same questions used to analyze Lady Gaga's song.

\section{Guided Practice}

- With support from both the English teacher and school psychologist, students work in small groups to identify two different scenes from the text, one where a character shows resilience, and one where a character fails to show resilience. Students analyze each scene using the same three questions used to analyze Lady Gaga's song. Discussion follows, facilitated by both educators.

- Students participate in "Take a Stand" activity. Students stand in a line in the middle of the room. The school psychologist reads real-life scenarios that present dilemmas in which the students might find themselves (failing a test, being bullied). Students step forward or backward to indicate how they would respond to the situation, selecting from two options that show resilience or lack of resilience.

\section{Independent Practice}

- For homework, students are asked to write a narrative in which they describe a time in their lives when they did not demonstrate resilience. After describing the event, students describe what they could have done differently to demonstrate resilience in that same situation.

\section{Closure}

- Students will retake the opening Likert-scale questionnaire and discuss with both educators if and why their responses to the questions about resilience have changed.

\section{Assessment}

- Students' ability to identify qualities of resilience will be evaluated by both educators based on their contributions during the various class discussions as well as in their written narrative. 